\title{
Vitamin D status of type 2 diabetic patients compared with healthy subjects in the Islamic Republic of Iran
}

\author{
M. Djalali, ${ }^{1}$ E. Taheri, ${ }^{1,2}$ A. Saedisomeolia, ${ }^{1}$ A. Djazayeri, ${ }^{1}$ A. Rahemi, ${ }^{3}$ M. Hashemi ${ }^{4}$ and B. Larijani ${ }^{2}$
}

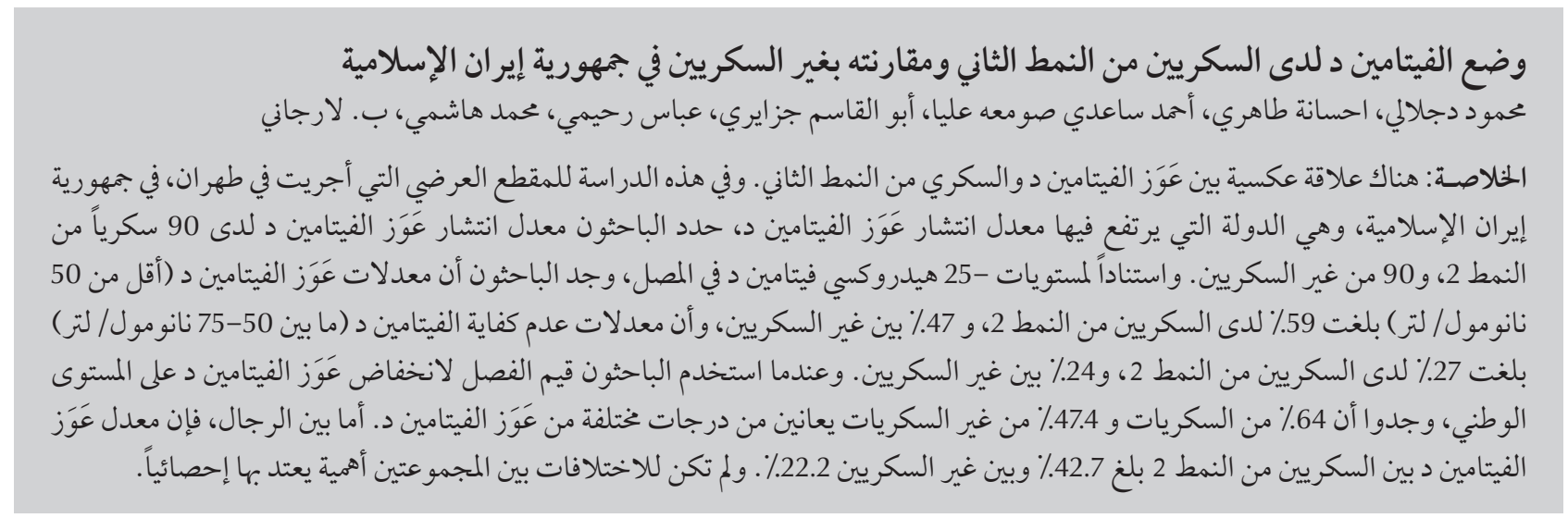

ABSTRACT An inverse relationship has been shown between vitamin D deficiency and type 2 diabetes mellitus (DM). In this cross-sectional study in Tehran, Islamic Republic of Iran, a country with a high prevalence of vitamin D deficiency, we determined the prevalence of vitamin D deficiency among 90 type 2 DM patients and 90 healthy subjects. Based on serum levels of 25-hydroxyvitamin D, the rates of deficiency $(<50 \mathrm{nmol} / \mathrm{L})$ and insufficiency $(50-75 \mathrm{nmol} / \mathrm{L})$ were $59.0 \%$ and $27.0 \%$ respectively in patients with type 2 DM, and $47.0 \%$ and $24.0 \%$ respectively in healthy subjects. Using the national cut-offs for vitamin D deficiency, $64.0 \%$ women with DM and $47.4 \%$ of healthy women were suffering from different degrees of vitamin D deficiency. The prevalence of vitamin D deficiency in men with type $2 \mathrm{DM}$ and healthy men were $42.7 \%$ and $22.2 \%$ respectively. None of the differences between the 2 groups was statistically significant.

Statut en vitamine $D$ de patients atteints d'un diabète de type 2 par rapport à des sujets en bonne santé en République islamique d'Iran

RÉSUMÉ Une relation inverse a été démontrée entre le déficit en vitamine $\mathrm{D}$ et le diabète de type 2. Dans le cadre de la présente étude transversale menée à Téhéran (République islamique d'Iran), dans un pays où la prévalence du déficit en vitamine D est élevée, nous avons mesuré cette prévalence chez 90 patients souffrant d'un diabète de type 2 et 90 sujets en bonne santé. D'après la concentration sérique de 25 -hydroxyvitamine D, le taux de prévalence du déficit ( $<50 \mathrm{nmol} / \mathrm{L})$ et de l'insuffisance en vitamine D $(50-75 \mathrm{nmol} / \mathrm{L})$ était respectivement de $59,0 \%$ et de $27,0 \%$ chez les patients diabétiques, contre $47,0 \%$ et $24,0 \%$ chez les sujets en bonne santé. Selon les seuils nationaux fixés pour le déficit en vitamine D, 64,0\% des femmes diabétiques et 47,4 \% des femmes en bonne santé présentaient un déficit en vitamine $\mathrm{D}$ à des degrés divers. La prévalence du déficit en vitamine D chez les hommes atteints d'un diabète de type 2 était de 42,7 \%, contre 22,2 \% chez les hommes en bonne santé. Aucune des différences entre les deux groupes n'était statistiquement significative.

${ }^{1}$ Department of Nutrition and Biochemistry; ${ }^{3}$ Department of Epidemiology and Biostatistics, School of Public Health, Tehran University of Medical Sciences, Tehran, Islamic Republic of Iran.

${ }^{2}$ Endocrinology and Metabolism Research Center, Endocrinology and Metabolism Clinical Sciences Institute, Tehran University of Medical Sciences, Tehran, Islamic Republic of Iran (Correspondence to E. Taheri: ehsaneh_taheri@yahoo.com).

${ }^{4}$ Tehran Naft Industry Hospital, Tehran, Islamic Republic of Iran.

Received: 18/04/12; accepted: 06/12/12 


\section{Introduction}

Type 2 diabetes mellitus (DM) is a metabolic disorder which is a major health problem in many countries in the world $[1,2]$. The World Health Organization (WHO) has predicted that the global prevalence of diabetes will increase from $2.8 \%$ in 2000 to $4.4 \%$ in 2030 [1]. Data from the third national Surveillance of Risk Factors of Non-Communicable Diseases study in the Islamic Republic of Iran reported that the prevalence of diabetes among Iranians aged 25-64 years was $7.7 \%$ and that $16.8 \%$ of adults, i.e. about 4.4 million people, had impaired fasting glucose $[2,3]$. Diabetes is the fifth leading cause of death in the Islamic Republic of Iran [4]

A main function of vitamin $D$ is to regulate calcium and phosphorus homeostasis and bone metabolism [5]. Also, in recent decades, research has shown that vitamin D has multiple non-skeletal roles in immune function regulation and in diseases such as hypertension, psoriasis, multiple sclerosis, colorectal disorders and prostate cancer [6-9]. It has been reported that there is an inverse relationship between circulating levels of vitamin $D$ and the prevalence of type $2 \mathrm{DM}$. In fact, vitamin $D$ deficiency has being suggested as a risk factors for type $2 \mathrm{DM}[10-13]$.

A high prevalence of vitamin $D$ deficiency among people with diabetes has been shown in different age groups in different cities of the Islamic Republic of Iran. The Iranian Multicentre Osteoporosis Study reported that $72.1 \%$ of men overall and $75.1 \%$ of women suffered from different degrees of vitamin D deficiency [14]. The aim of the present study was to determine vitamin D status among type 2 diabetic patients compared with healthy subjects.

\section{Methods}

\section{Study design and sample}

In this cross-sectional study, 180 subjects (aged 20-80 years) including 90 type 2 diabetic patients from the Iranian Diabetes Association clinics and 90 healthy subjects from the staff of Tehran University of Medical Sciences were selected via random sampling methods. A sample size of 180 subjects including 90 diabetic patients and 90 healthy subjects was used to allow determination of differences with $80 \%$ power. Age and sex were matched between the 2 groups. The exclusion criteria were: pregnancy or lactation; use of drugs that could affect the lipid profile or calcium and bone metabolism; chronic disorders of the liver or kidney; endocrinological disorders such as hypo- or hyperthyroidism or parathyroidism; smoking; insulin injection; use of anticonvulsant drugs; or use of vitamin $\mathrm{D}$ or calcium supplements.

\section{Data collection}

Due to the important effect of sunlight on vitamin D levels, we would expect to observe the lowest levels of 25-hydroxyvitamin $\mathrm{D}[25(\mathrm{OH}) \mathrm{D}]$ in winter and the highest levels in summer. To minimize the seasonal variability in means level of vitamin D our sampling was therefore performed from April to June 2011.

Written consent (using a form approved by the ethics committee of Tehran University of Medical Sciences) was taken from each participant. After an overnight fast, $10 \mathrm{~mL}$ of peripheral blood was taken. The blood samples were centrifuged at $3000 \mathrm{rpm}$ for 10 min and stored at $-20^{\circ} \mathrm{C}$. All biochemical measurements were performed in the laboratory of the Department of Nutrition and Biochemistry, School of Public Health, Tehran University of Medical Sciences according to the External Quality Assessment programme.

\section{Laboratory tests}

Serum concentrations of $25(\mathrm{OH})$ $\mathrm{D}$ were measured using chemiluminescence immunoassay (DiaSorin). Serum 25(OH)D levels were classified as follows: $>75 \mathrm{nmol} / \mathrm{L}$ vitamin $\mathrm{D}$ sufficiency; 50-75 nmol/L vitamin D insufficiency and $<50 \mathrm{nmol} / \mathrm{L}$ vitamin $\mathrm{D}$ deficiency. Within the deficiency category serum levels of $25(\mathrm{OH}) \mathrm{D}$ were further classified as: $>25<39.9 \mathrm{nmol} / \mathrm{L}$ mild deficiency; $>12.5<25 \mathrm{nmol} / \mathrm{L}$ moderate deficiency and $\leq 12.5 \mathrm{nmol} / \mathrm{L}$ severe deficiency. Inter-assay and intraassay variation values for $25(\mathrm{OH}) \mathrm{D}$ were $8.0 \%$ and $6.8 \%$ respectively.

Serum levels of parathyroid hormone (PTH) were measured using a radioimmunoassay kit (RIA) (Cisbio International) with normal range of 8-79 pg/mL. Inter-assay and intraassay variations for PTH were $8.9 \%$ and $6.1 \%$ respectively.

Serum calcium and phosphorus were analysed using serum calcium and phosphate was measured on a clinical analyser (Hitachi 917). Normal ranges of calcium and phosphorous were defined as $8.6-10.3 \mathrm{mg} / \mathrm{dL}$ and $2.5-5$ $\mathrm{mg} / \mathrm{dL}$ respectively. The Inter-assay and intra-assay variations of serum calcium were $3.0 \%$ and $2.0 \%$ and for phosphate were $3.0 \%$ and $2.5 \%$.

\section{Definitions}

The "normal" range of vitamin D varies depends on the reference laboratory, seasonal effects, etc. In some researches, 25(OH)D levels 25-50, $50-75$ and $>75 \mathrm{nmol} / \mathrm{L}$ are defined as severe, moderate and mild vitamin D deficiency respectively. In other studies, $25(\mathrm{OH}) \mathrm{D}<50 \mathrm{nmol} / \mathrm{L}$ is considered as vitamin $\mathrm{D}$ deficiency and $50-75$ $\mathrm{nmol} / \mathrm{L}$ as vitamin $\mathrm{D}$ insufficiency [15]. Because there is differences in mean serum concentration of $25(\mathrm{OH})$ $\mathrm{D}$ in different regions and racial groups [16] it has been proposed that "target" concentrations of $25(\mathrm{OH}) \mathrm{D}$ are used instead of so-called normal ranges. The target concentration of $25(\mathrm{OH}) \mathrm{D}$ is the serum level of $25(\mathrm{OH}) \mathrm{D}$ at which the mean serum level of PTH starts to increase in the population. We used the cut-offs of Moradzadeh et al., who categorized vitamin D status on the basis of an inverse relationship between 
serum levels of 25(OH)D and PTH according to the Iranian Multicentre Osteoporosis Study's data for the Iranian population of men and women separately [17].

\section{Anthropometric data}

Anthropometric data including weight and height were measured using a Seca scale (Seca 725) while subjects wore light clothes and no shoes. The accuracy of weight and height measurements was to nearest to $100 \mathrm{~g}$ and $0.5 \mathrm{~cm}$ respectively. Body mass index (BMI) was defined as weight $(\mathrm{kg})$ divided to height squared $\left(\mathrm{m}^{2}\right)$.

\section{Daily sunlight exposure}

In a simple self-administered questionnaire participants were asked to estimate the daily amount of time they were exposed to sunlight. Sunlight exposure was defined as inadequate if estimated hand and face exposure was $<30 \mathrm{~min}$ per day and adequate if it was $\geq 30 \mathrm{~min}$ per day.

\section{Data analysis}

The data were analysed using SPSS, version 16. Values were expressed as percentages and mean and standard deviation (SD). Student $t$-test was used to compare the differences between the means of variables. In all tests, $P$-values $<0.05$ were defined as significant differences.

\section{Results}

The study was performed on 180 individuals: 90 patients with type $2 \mathrm{DM}$ (47 women and 43 men) and 90 healthy subjects ( 48 women and 42 men).

The mean age, weight, BMI and serum levels of $25(\mathrm{OH}) \mathrm{D}, \mathrm{PTH}$, calcium and phosphorous in DM patients and healthy subjects are shown in Table 1 . There were no significant differences between the 2 groups in any of the variables studied, except for the serum calcium level, which was lower, but not significantly so, in the DM group compared with the controls [8.94 (SD 0.59 ) versus $9.14(\mathrm{SD} 0.53) \mathrm{mg} / \mathrm{dL}$ respectively] $(P=0.26)$. Notably, the $25(\mathrm{OH}) \mathrm{D}$ level was almost identical in the DM and control groups [22.1 (SD 15.2) versus $22.2(\mathrm{SD} 10.0) \mathrm{ng} / \mathrm{mL}$ respectively] $(P=0.75)$.

The prevalence of vitamin $D$ deficiency, insufficiency and sufficiency are shown in Table 2. The prevalence of vitamin $\mathrm{D}$ deficiency was $58.9 \%$ in type 2 DM patients and $47.0 \%$ in healthy subjects. Although the rate of vitamin D insufficiency was higher in the DM patients than the healthy subjects $(26.7 \%$ versus $24.4 \%$ ), the difference was not statistically significant $\left(\chi^{2}=0.21 ; \mathrm{df}=2\right.$; $P=0.89)$.

Using Moradzadeh et al's cut-offs [17], there were differences in the category of vitamin $\mathrm{D}$ deficiency between men and women; $25(\mathrm{OH}) \mathrm{D}$ level $\leq 25 \mathrm{nmol} / \mathrm{L}$ was considered as severe/moderate vitamin D deficiency and 25-39.9 nmol/L was considered as mild deficiency.

Vitamin D status in our population is shown in Table 3 for men and Table 4 for women. Among females $64.0 \%$ of DM patients and $47.4 \%$ of controls had vitamin $\mathrm{D}$ deficiency $(\leq 39.9 \mathrm{nmol} / \mathrm{L})$ $\left(\chi^{2}=1.17 ; \mathrm{df}=1 ; P=0.20\right)$, while among males $42.7 \%$ of DM and $22.2 \%$ of controls had vitamin $\mathrm{D}$ deficiency $\left(\chi^{2}=\right.$ $0.55 ; \mathrm{df}=1 ; P=0.25)$.

Figure 1 shows the amount of sunlight exposure in type $2 \mathrm{DM}$ patients and healthysubjects. The results showed that exposure to sunlight $\leq 30$ min per day was higher, but not significantly so, in type $2 \mathrm{DM}$ patients compared with health subjects.

\section{Discussion}

Normal levels of serum vitamin D are a matter of debate and there are multiple categorizations for defining vitamin $\mathrm{D}$ status $[18,19]$. Also, the accuracy of a variety methods used to measure $25(\mathrm{OH})$ D level are different. In Neyestani et al.'s study, serum concentrations of $25(\mathrm{OH})$ $\mathrm{D}$ were measured by 3 methods including HPLC, competitive protein-binding assay and RIA [20]. Although the most

\begin{tabular}{|c|c|c|c|}
\hline \multirow[t]{2}{*}{ Variable } & $\begin{array}{c}\text { Type } 2 \text { diabetes } \\
(n=90)\end{array}$ & $\begin{array}{l}\text { Controls } \\
(n=90)\end{array}$ & $P$-value ${ }^{a}$ \\
\hline & Mean (SD) & Mean (SD) & \\
\hline Age (years) & $51.3(11.2)$ & $51.6(13.4)$ & 0.88 \\
\hline Weight (kg) & $77.0(13.8)$ & $73.2(13.0)$ & 0.09 \\
\hline $\mathrm{BMI}\left(\mathrm{kg} / \mathrm{m}^{2}\right)$ & $26.2(9.3)$ & $26.3(4.6)$ & 0.98 \\
\hline Serum calcium (mg/dL) & $8.94(0.59)$ & $9.14(0.53)$ & 0.02 \\
\hline Serum phosphorous (mg/dL) & $3.66(0.03)$ & $3.70(0.04)$ & 0.59 \\
\hline Serum PTH (pmol/L) & $47.3(18.8)$ & $46.0(26.8)$ & 0.10 \\
\hline Serum 25(OH)D (ng/mL) & $22.1(15.2)$ & $22.2(10.0)$ & 0.75 \\
\hline
\end{tabular}

aType 2 diabetes mellitus versus controls: $t$-test.

$B M I=$ body mass index; $P T H=$ parathyroid hormone; $25(\mathrm{OH}) D=25$-hydroxyvitamin $D ; S D=$ standard deviation. 


\begin{tabular}{|c|c|c|c|c|c|c|}
\hline \multicolumn{7}{|c|}{$\begin{array}{l}\text { Table } 2 \text { Prevalence of vitamin D deficiency based on levels of 25-hydroxyvitamin D in type } 2 \text { diabetes mellitus patients and } \\
\text { healthy subjects }\end{array}$} \\
\hline \multirow[t]{2}{*}{ Group } & \multicolumn{2}{|c|}{$\begin{array}{l}\text { Vitamin D deficiency } \\
\quad(<50 \mathrm{nmol} / \mathrm{L})\end{array}$} & \multicolumn{2}{|c|}{$\begin{array}{l}\text { Vitamin D insufficiency } \\
\quad(50-75 \mathrm{nmol} / \mathrm{L})\end{array}$} & \multicolumn{2}{|c|}{$\begin{array}{l}\text { Vitamin D sufficiency } \\
\text { (75 nmol/L) }\end{array}$} \\
\hline & No. & $\%$ & No. & $\%$ & No. & $\%$ \\
\hline Type 2 diabetes $(n=90)$ & 53 & 58.9 & 24 & 26.7 & 13 & 14.4 \\
\hline Controls $(n=90)$ & 42 & 47.0 & 22 & 24.4 & 26 & 28.9 \\
\hline
\end{tabular}

Type 2 diabetes mellitus versus controls: $\chi^{2}=0.21 ; d f=2 ; P=0.89$

\begin{tabular}{|c|c|c|c|c|c|c|c|c|}
\hline \multirow[t]{2}{*}{ Group } & \multicolumn{2}{|c|}{$\begin{array}{l}\text { Total deficiency } \\
(\leq 39.9 \mathrm{nmol} / \mathrm{L})\end{array}$} & \multicolumn{2}{|c|}{$\begin{array}{l}\text { Severe deficiency } \\
(<12.5 \mathrm{nmol} / \mathrm{L})\end{array}$} & \multicolumn{2}{|c|}{$\begin{array}{l}\text { Medium deficiency } \\
(12.5-24.9 \mathrm{nmol} / \mathrm{L})\end{array}$} & \multicolumn{2}{|c|}{$\begin{array}{l}\text { Mild deficiency } \\
(25-39.9 \mathrm{nmol} / \mathrm{L})\end{array}$} \\
\hline & No. & $\%$ & No. & $\%$ & No. & $\%$ & No. & $\%$ \\
\hline Type 2 diabetes $(n=47)$ & 31 & 66.0 & 3 & 6.4 & 13 & 27.7 & 15 & 31.9 \\
\hline Controls $(n=48)$ & 23 & 47.9 & 1 & 2.1 & 8 & 16.7 & 14 & 29.2 \\
\hline
\end{tabular}

Type 2 diabetes mellitus versus controls: $\chi^{2}=1.17 ; d f=1 ; P=0.20$.

valid method for determining $25(\mathrm{OH})$ $\mathrm{D}$ is HPLC-atmospheric pressure chemical ionization-mass spectrometry [18], chemiluminescence immunoassay detection using microplate illuminometers, as used in our study, provides a sensitive, high throughput and economical alternative to conventional colorimetric methodologies, such as enzyme-linked immunosorbent assay.

In our study the prevalence of vitamin $\mathrm{D}$ deficiency was $83.3 \%$ in type 2 DM patients and $75.6 \%$ in healthy subjects matched for age and sex. There are several likely causes for this high prevalence of vitamin $\mathrm{D}$ deficiency in the Iranian population. Foods in the Islamic Republic of Iran are not fortified with vitamin $\mathrm{D}$ and it is therefore not surprising that the level of vitamin D deficiency may be high in our country. Only a few foods naturally contain significant amounts of vitamin $\mathrm{D}$, particularly fish such as sardines, salmon, herring and mackerel, and in countries where foodstuffs are fortified with vitamin $\mathrm{D}$, the prevalence of vitamin $\mathrm{D}$ deficiency is $1.6 \%-14.8 \%$ in different age groups $[21,22]$. The main source of vitamin D in humans, however, is conversion of 7-dehydrocholesterol in skin to pre-vitamin $\mathrm{D}$ and then vitamin D by absorption of UVB radiation from sunlight [23], as less UVB radiation reaches the earth's surface in winter in the northern hemisphere [24]. Tehran city is located at $36^{\circ} 2^{\prime} \mathrm{N}$ and the mean amount of sunlight radiation is 8 hours per day [25]. Nevertheless, several factors can affect cutaneous production of vitamin $\mathrm{D}$, including season, time of day, latitude, skin pigmentation, skin coverage by clothes and use of sunscreens [26]. Previous studies have shown a high prevalence of vitamin $D$ deficiency in sunny countries at lower latitudes such as India, Turkey and Saudi Arabia $[27,28]$. This may be because melanin pigmentation acts as natural sunscreen; very dark-skinned people require about 1.5 hours exposure to sunlight daily for synthesizing vitamin $D$, which is 6 times longer than the 15 minutes required for light-skinned people [29]. Clothing habits and full body covering, especially among women who live in the Middle East and Muslim countries such Turkey, Saudi Arabia, Jordan, Lebanon and Islamic Republic of Iran, may be another reason for the high prevalence of vitamin $\mathrm{D}$ deficiency in these areas $[27,28]$. Current indoor lifestyles may be reducing sunlight exposure and contributing to an increasing prevalence of vitamin $\mathrm{D}$ particularly in developed countries and in urban areas. Tehran is one of the most highly polluted cities in the world [30]. Air pollution, by

\begin{tabular}{|c|c|c|c|c|c|c|}
\hline \multirow[t]{2}{*}{ Group } & \multicolumn{2}{|c|}{$\begin{array}{l}\text { Total deficiency } \\
(\leq 39.9 \mathrm{nmol} / \mathrm{L})\end{array}$} & \multicolumn{2}{|c|}{$\begin{array}{l}\text { Severe or medium deficiency } \\
\qquad(<25 \mathrm{nmol} / \mathrm{L})\end{array}$} & \multicolumn{2}{|c|}{$\begin{array}{l}\text { Mild deficiency } \\
(25-39.9 \mathrm{nmol} / \mathrm{L})\end{array}$} \\
\hline & No. & $\%$ & No. & $\%$ & No. & $\%$ \\
\hline Type 2 diabetes $(n=42)$ & 18 & 42.9 & 6 & 14.3 & 12 & 28.6 \\
\hline Controls $(n=43)$ & 10 & 23.3 & 3 & 7.0 & 7 & 16.3 \\
\hline
\end{tabular}

Type 2 diabetes mellitus versus controls: $\chi^{2}=0.55 ; d f=1 ; P=0.25$. 


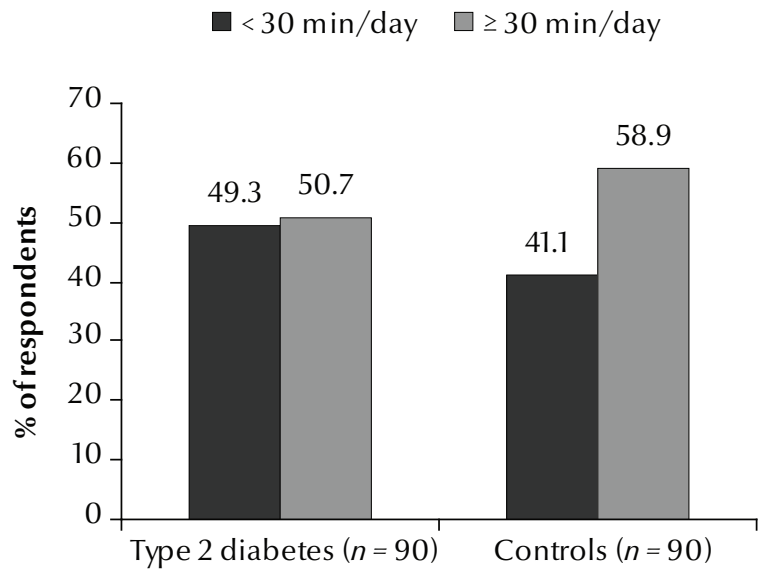

Figure 1 Sunlight exposure in type 2 diabetes mellitus patients and healthy subjects

absorbing sunlight radiation, may decrease cutaneous vitamin D synthesis and therefore may be another cause of vitamin D deficiency in our study [31].

There was no statistically significant difference in the current study between the rate of vitamin $\mathrm{D}$ deficiency in type $2 \mathrm{DM}$ patients and healthy subjects, and although a slightly higher percentage of DM patients compared with controls had sunlight exposure $<30 \mathrm{~min} /$ day, this was also not significant. Ataie-Jafari et al. have shown a high prevalence of vitamin $\mathrm{D}$ deficiency in children and adolescents with type $1 \mathrm{DM}$. Also, boys with $\geq 15 \mathrm{~min} /$ day sunlight exposure were less likely to be vitamin $\mathrm{D}$ deficient compared with girls and those with sunlight exposure $<15 \mathrm{~min} /$ day [26]. Sherin-Zadeh et al. in the Islamic Republic of Iran demonstrated that among 61 type 2 DM patients from Tehran, $78.7 \%$ of patients had vitamin $\mathrm{D}$ deficiency [serum 25(OH)D level $<20 \mathrm{ng} / \mathrm{mL}$ ] [unpublished data]. Hossein-Nezhad et al., in a cross-sectional study of 646 healthy people in Tehran, showed that the unadjusted prevalence of metabolic syndrome was $18.3 \%$ (29.0\% in men and $14.6 \%$ in women) and the total prevalence of vitamin $\mathrm{D}$ deficiency was $72.3 \%$ [22]. It has been also shown that, after adjustment for age and sex, vitamin $\mathrm{D}$ deficiency predicted metabolic syndrome independently. In their study vitamin $\mathrm{D}$ deficiency was defined as serum $25(\mathrm{OH}) \mathrm{D}$ concentration $\leq 34.9$ $\mathrm{nmol} / \mathrm{L}$ and normal as $\geq 35 \mathrm{nmol} / \mathrm{L} \mathrm{ac}$ cording to Hashemipour et al.'s criteria [21]. Neyestani et al., in order to assess vitamin D status in Iranian diabetics, performed a study on 90 subjects including 30 type $1 \mathrm{DM}, 30$ type $2 \mathrm{DM}$ and 30 healthy subjects during fall and winter [23]. In their study serum levels of $25(\mathrm{OH}) \mathrm{D}$ were categorized as follows: sufficiency $\geq 37 \mathrm{nmol} / \mathrm{L}$, mild deficiency $25-37 \mathrm{nmol} / \mathrm{L}$, moderate deficiency $12.5-25 \mathrm{nmol} / \mathrm{L}$ and severe deficiency $<12.5 \mathrm{nmol} / \mathrm{L}$. The results suggested that the prevalence of vitamin $\mathrm{D}$ deficiency was almost the same in patients with type $1 \mathrm{DM}$ and in healthy controls. Mean serum levels of $25(\mathrm{OH})$ $D$ in patients with type $2 \mathrm{DM}$ were higher than type $1 \mathrm{DM}$ only when using high performance liquid chromatography (HPLC).

This study had some limitations. A random measurement error may occur due the use of a single measurement of $25(\mathrm{OH}) \mathrm{D}$ in patients. The sample size was small and it is suggested that the study be performed in a larger sample of type 2 DM patients and with different durations of diabetes. We did not use of direct methods for measuring sunlight exposure and we did not record subjects' use of sunscreen creams.

In conclusion, vitamin $\mathrm{D}$ deficiency is a major health problem among both type $2 \mathrm{DM}$ patients and healthy subjects in this Iranian population.

\section{Acknowledgements}

Funding: This study was financially supported by Tehran University of Medical Science research grant (grant no. 10091).

Competing interests: None declared..

\section{References}

1. Wild S et al. Global prevalence of diabetes: estimates for the year 2000 and projections for 2030. Diabetes Care, 2004, 27:1047-1053.

2. Haghdoost A et al. Prevalence of type 2 diabetes in the Islamic Republic of Iran: systematic review and meta-analysis. Eastern Mediterranean Health Journal, 2009, 15:591-599.

3. Esteghamati A et al. Third National Surveillance of Risk Factors of Non-Communicable Diseases (SuRFNCD-2007) in Iran: methods and results on prevalence of diabetes, hypertension, obesity, central obesity, and dyslipidemia. BMC Public Health, 2009, 9:167.
4. Esteghamati A et al. Prevalence of diabetes and impaired fasting glucose in the adult population of Iran. Diabetes Care, 2008, 31:96.

5. Heaney RP. Functional indices of vitamin D status and ramifications of vitamin D deficiency. American Journal of Clinical Nutrition, 2004, 80:1706S.

6. Holick MF. High prevalence of vitamin D inadequacy and implications for health. Mayo Clinic Proceedings, 2006, 81(3):353-373.

7. Bischoff-Ferrari HA et al. Estimation of optimal serum concentrations of 25-hydroxyvitamin D for multiple health outcomes. American Journal of Clinical Nutrition, 2006, 84:18. 
8. Holick MF. Vitamin D deficiency. New England Journal of Medicine, 2007, 357:266-281.

9. Zittermann A. Vitamin D and disease prevention with special reference to cardiovascular disease. Progress in Biophysics and Molecular Biology, 2006, 92:39-48.

10. Pittas AG et al. Vitamin D and calcium intake in relation to type 2 diabetes in women. Diabetes Care, 2006, 29:650.

11. Pittas AG. et al. The role of vitamin D and calcium in type 2 diabetes. A systematic review and meta-analysis. Journal of Clinical Endocrinology and Metabolism, 2007, 92(6):2017-2029.

12. Isaia G, Giorgino R, Adami S. High prevalence of hypovitaminosis $\mathrm{D}$ in female type 2 diabetic population. Diabetes Care, 2001, 24:1496.

13. Mattila C et al. Serum 25-hydroxyvitamin D concentration and subsequent risk of type 2 diabetes. Diabetes Care, 2007, 30:2569.

14. Heshmat R et al. Vitamin D deficiency in Iran: a multi-center study among different urban areas. Iranian Journal of Public Health, 2008, Suppl. 1:72-78.

15. Holick MF. Vitamin D status: measurement, interpretation, and clinical application. Annals of Epidemiology, 2009, 19:73-78.

16. Zittermann A et al. Vitamin D deficiency and mortality risk in the general population: a meta-analysis of prospective cohort studies. American Journal of Clinical Nutrition, 2012, 95:91-100.

17. Moradzadeh $\mathrm{K}$ et al. Normative values of vitamin $\mathrm{D}$ among Iranian population: a population based study. International Journal of Osteoporosis and Metabolic Disorders, 2008, 1:8-15.

18. Snellman G et al. Determining vitamin D status: a comparison between commercially available assays. PLOS ONE, 2010, 5:e11555.

19. Thacher TD, Clarke BL. Vitamin D insufficiency. Mayo Clinic Proceedings, 2011, 86(1):50-60.

20. Neyestani T, Gharavi A, Kalayi A. Iranian diabetics may not be vitamin D deficient more than healthy subjects. Acta Medica Iranica, 2008, 46:337-341.
21. Omdahl JL et al. Nutritional status in a healthy elderly population: vitamin D. American Journal of Clinical Nutrition, 1982, $36: 1225-1233$

22. Kinyamu $\mathrm{H}$ et al. Serum vitamin $\mathrm{D}$ metabolites and calcium absorption in normal young and elderly free-living women and in women living in nursing homes. American Journal of Clinical Nutrition, 1997, 65:790-797.

23. Holick MF, Garabedian M. Vitamin D: photobiology, metabolism, mechanism of action, and clinical applications. In: Rosen CJ. Compston JE, Lian JB, eds. Primer on the metabolic bone diseases and disorders of mineral metabolism, 6th ed. Washington DC, American Society for Bone and Mineral Research, 2006:129-137.

24. Holick MF et al. Evaluation, treatment, and prevention of vitamin D deficiency: an Endocrine Society clinical practice guideline. Journal of Clinical Endocrinology and Metabolism, 2011, 96:1911-1930.

25. Ataie-Jafari A et al. The influence of sunlight exposure on serum vitamin D concentration and bone turnover; a controlled clinical trial. Iranian Journal of Public Health, 2008, Suppl. 1:41-48.

26. Wolpowitz D, Gilchrest BA. The vitamin D questions: how much do you need and how should you get it? Journal of the American Academy of Dermatology, 2006, 54:301-317.

27. Lips P. Worldwide status of vitamin D nutrition. Journal of Steroid Biochemistry and Molecular Biology, 2010, 121:297-300.

28. Mithal A et al. Global vitamin D status and determinants of hypovitaminosis D. Osteoporosis International, 2009, 20:18071820.

29. Webb AR, Engelsen O. Calculated ultraviolet exposure levels for a healthy vitamin D status. Photochemistry and Photobiology, 2006, 82:1697-1703.

30. Mehrdad R. Health system in Iran. Japan Medical Association Journal, 2009, 52:69-73.

31. Hosseinpanah $\mathrm{F}$ et al. The effects of air pollution on vitamin D status in healthy women: a cross sectional study. BMC Public Health, 2010, 10:519. 